\title{
THE STUDY OF BEHAVIOR EVALUATION SURVEY: FAMILY HEALTH
}

\author{
Teungku Nih Farisni ${ }^{1}$, Yarmaliza $^{2}$, Fitriani $^{3}$, Fitrah Reynaldi $^{4}$ \\ Faculty Of Public Health, Teuku Umar Univerty, Indonesia. \\ Coresponding Author: teungkunihfarisni@utu.ac.id
}

\begin{abstract}
The Family health is one of the efforts in health development to encourage overall human development which needs to be considered early on. Ministry of Health 2013, households in Indonesia with PHBS reached 55.6\%. Bale Village has health problems that are not paying attention to the cleanliness of the surrounding environment, such as littering, food waste that causes flies and can cause various diseases such as diarrhea. This survey research was conducted in July 2018 which aims to see how behavioral evaluations will affect family health. The research population of all communities in PT. Mifa Brothers in West Aceh Regency as many as 261 houses with a sample using total sampling, which is 261 houses with the target interview (Indep Interview) is the head of the family and mother. Data were analyzed univariately and by measurement of a healthy family index. The results of the study found that the low healthy living behavior of the community by not using family planning was 143 households $(54.8 \%)$, while for smokers' families were 245 households $(93.9 \%)$. It can be concluded that the number of unhealthy families is 178 households $(68.2 \%)$, the number of healthy families is 83 households $(31.8 \%)$, the total number of healthy families index is $31.8 \%$ of all unhealthy families. It is expected that the community will be able to increase knowledge of healthy behaviors that will affect family health by coordinating with relevant agencies in various health programs.
\end{abstract}

\section{Keywords: Family Behavior and Health}

\section{Introduction}

The essence of national development covers all dimensions and aspects of life including population development and family development. Population as the basic capital and the dominant factor of development must be a central point in sustainable development. Success in realizing a balanced population growth and developing the quality of the population and family will improve all aspects of the dimensions of development and community life in accordance with Law No. 52 of 2009 concerning Population and Family Development.

In the framework of the implementation of the Healthy Indonesia Program with a family approach, 12 (twelve) key indicators have been established as markers of a family's health status namely, membership of the family planning program for fertile age couples, antenatal care for pregnant women, infant immunization, exclusive breastfeeding, monitoring infant growth , 
adherence to treatment in patients with TB, head of treatment in patients with hypertension. In order for this healthy family program to succeed, the key is community empowerment and crosssector synergy. In community empowerment, the role of health workers is a companion. The community is expected to be able to make changes together and independently through Community-Based Health Efforts (UKBM).

Based on data from the Indonesian Ministry of Health (Kemenkes) in 2013, the coverage of clean and healthy living behavior in Central Java was $75.1 \%$, this achievement has met the target when compared with the national Strategic Plan for 2010-2014 which was 70\%. Based on data from the Health Profile of Sukoharjo Regency in 2013, from 114,140 households examined by PHBS, 96,922 households had adopted clean and healthy living behaviors, meaning that as many as $82.2 \%$ of the people had adopted clean and healthy living behaviors.

The maternal mortality rate has decreased, but it is still far from the MDG target in 2015, although the number of deliveries assisted by health workers has increased. This condition is likely caused by, among others, the inadequate quality of maternal health services, the condition of unhealthy pregnant women and other determinant factors. The main causes of maternal death are hypertension in pregnancy and post partum hemorrhage. This cause can be minimized if the quality of antenatal care is well implemented.

Improvement and expansion of family planning services is one of the government's efforts to reduce the high morbidity and maternal mortality due to pregnancy experienced by women. In addition to reducing the number of births, the Government launched a National Family Planning movement with the aim of creating a prosperous small family that is the basis for the realization of the fifth precepts, namely social justice for all the people of Indonesia. This program introduces the public to various types of contraceptives that can be used to prevent unwanted pregnancies and regulate the number of children desired so that it is expected that the number of births from year to year can be controlled through this program.

Some description of the condition of pregnant women is not healthy, such as handling complications, anemia, pregnant women who have diabetes, high blood pressure, and four too (too young $<20$ years, too old $>35$ years, too close to 2 years apart (not using $\mathrm{KB}$ ), and too many children $>3$ people). As many as 54.2 per 1000 women under the age of 20 have given birth, while women giving birth over the age of 40 are 207 per 1000 live births. This problem is 
compounded by the fact that there is still the age of first marriage at a very young age $(<20$ years) as many as $46.7 \%$ of all married women (Ministry of Health Republic of Indonesia 2016). Based on data from the settlement of PT. Mifa Bersaudara (2018) the number of villages in the settlement is 3 villages with the total number of houses in the three villages is 261 houses namely Balee village with 133 houses, Reudep village with 50 houses and Sumber Batu village with 78 houses.

Based on the results of interviews with each keuchik as the village head in the three villages the researchers found that Bale Village had health problems in the environment where the surrounding community paid less attention to the cleanliness of the surrounding environment by littering like food waste that caused flies and could cause various diseases. like diarrhea. Furthermore, the Reudeup village based on an interview with Keuchik, this village has a health problem in the community's awareness of clean living habits where the people here after work rarely bathe and change clothes, they often sit around and this causes them to often experience skin diseases such as dermatitis and tinea. Then Sumber Batu village based on an interview with the keuchik stated that the community in this village has a lack of awareness about family health, which according to the report of health workers complained about the level of community attendance in posyandu activities for maternal and child health checks and poslansia for the examination of elderly people along with the examination free health services provided by puskesmas and the Health Service.

Based on the results of interviews with 6 people from 3 villages where 2 Bale villages stated that they often experience abdominal pain such as diarrhea and vomiting diarrhea, this is based on the results of the examination by health workers due to unclean lifestyle and environment, such as not washing their hands when eating and does not close food well on the table and rubbish that is scattered everywhere. There are some people who do not use family planning for various reasons, other conditions are still found in some family members who are still actively smoking. Based on these problems it is deemed necessary to conduct research on healthy behaviors that can affect family health in PT. Mifa Brothers in West Aceh Regency.

\section{METHODE}

This research is a survey and was conducted in July 2018, while the purpose of the study was to see how behavioral evaluations would affect family health in PT. Mifa brothers in West Aceh Regency. The population of this research is all the people in PT. Mifa Brothers in West 
Aceh Regency. The population of 261 houses with a sample using total sampling, which is 261 houses with the target interview (Indep Interview) is the head of the family and mother. Data were analyzed univariately and by measurement of healthy family index (IKS):

$$
\mathrm{KS}=\frac{\text { Number of Healhty homes or household } \mathrm{x} 100 \%}{\text { number of house or }(\mathrm{KK})}
$$

\section{RESULT:}

Univariate Analysis

Table 1. Distribution of Respondents by Village Settlement of PT. Mifa Brothers in West Aceh Regency

\begin{tabular}{ccc}
\hline Village & Frequency & Percent (\%) \\
\hline Sumber Batu & 78 & $29,9 \%$ \\
\hline Reudep & 50 & $19,2 \%$ \\
\hline Bale & 133 & $51,0 \%$ \\
\hline Total & 261 & $100.0 \%$ \\
\hline
\end{tabular}

In Table 1. It shows the villages with the highest number of respondents found in Balee village, which totaled $133(51.0 \%)$, for the village with the lowest number of respondents being in Reudep Village, which was 50 (19.2\%).

\section{Use of KB}

Table 2. Distribution of Respondents Based on the Use of KB by Respondents in the Settlement of PT. Mifa Brothers in West Aceh Regency

\begin{tabular}{ccc}
\hline Use of KB & Frequency & Percent (\%) \\
\hline Not Healthy & 143 & $54.8 \%$ \\
\hline Healthy & 118 & $45.2 \%$ \\
\hline Total & 261 & $100.0 \%$ \\
\hline
\end{tabular}

Source: primary data 2018

In Table 2. shows that respondents with unhealthy family planning use are $143(54,8 \%)$. 


\section{Family members smoke}

Table 3. Distribution of Respondents by Family Members of Smoking in Settlement of PT. Mifa Brothers in West Aceh Regency
Family members smoke
Frequency
Percent $(\%)$

\begin{tabular}{ccc}
\hline Not Healthy & 245 & $93.9 \%$ \\
\hline Healthy & 16 & $6.1 \%$ \\
\hline Total & 261 & $100.0 \%$ \\
\hline
\end{tabular}

Source: primary data 2018

In Table 3. Shows that respondents with unhealthy smoking family members number 245 $(93.9 \%)$.

\section{Family health}

Table 4. Distribution of Respondents by Family Health in the Settlement of PT. Mifa Brothers in West Aceh Regency

\begin{tabular}{ccc}
\hline Kesehatan Keluarga & Frequency & Percent (\%) \\
\hline Not Healthy & 178 & $68.2 \%$ \\
\hline Healthy & 83 & $31.8 \%$ \\
\hline Total & 261 & $100.0 \%$ \\
\hline
\end{tabular}

Source: primary data 2018

In Table 4. It shows 178 respondents (68.2\%) with unhealthy family health.

\section{Healthy Family Index Analysis}

The measurement of a healthy family index (IKS) can be done with the following formula (Kemeneks RI, 2015):

$$
\text { KS: } \frac{\text { Number of Healhty homes or household x } 100 \%}{\text { number of house or (KK) }}
$$

$\mathrm{IKS}=\frac{83}{261}$

$$
\mathrm{IKS}=0,318 \times 100 \%
$$




$$
\mathrm{IKS}=31,8 \%
$$

The number of healthy family index as much as $31.8 \%$ of the overall unhealthy family.

\section{DISCUSSION}

\section{Use of KB}

Based on the results of research in the field that researchers do in fact there are still many families in the settlement of PT. MIFA does not use KB. This happens because some families cannot use birth control due to health problems such as if it is crowded, and tired quickly. There are also some who say that since they use family planning, they are getting fatter so they don't want to use family planning anymore. There are also families who do not use family planning however, the program itself has its child.

Family planning is one way to limit the number of children. Therefore, the Government launched a program or way to prevent and delay pregnancy. The purpose of implementing the family planning program is to form a small family in accordance with the socio-economic strength of a family by regulating the birth of a child in order to obtain a happy and prosperous family so that quality of life can be fulfilled. (Sulistyawati, 2013).

The decision factor for family planning users to use contraception is inseparable from the behavior factors owned by each individual (Rahma, 2011). The factors that are the cause of the behavior of choosing contraception can be explained by According to Notoatmodjo (2003) which is divided into three types, namely: 1) Predisposing Factors (Predisposing Factors) Is an internal factor that exists in individuals, families, groups or communities that facilitate individuals to determine the contraception to be used, the intended predisposing factors are age, education, occupation and number of children. 2) Supporting factors (Enabling Factors) Is a factor that allows individuals to behave in choosing contraception.

Due to the availability of human resources, affordability, referrals and skills, the existence of health facilities that support family planning programs will influence the behavior of mothers in choosing contraceptive methods, which means the supporting factors are contraceptive safety, contraceptive availability, and contraceptive services. 3) Reinforcing Factor Is a factor that reinforces behavior, such as the attitudes and skills of health workers or other 
officers who are a reference group of community behavior, which means the health factor, contraception costs, husband support, socio-cultural, economics (Notoatmodjo, 2003).

The ignorance of women of childbearing age about contraceptives is influenced by a lack of information and most are educated in elementary school. The higher a person's education, the easier it is to receive information. Environmental factors are all conditions that exist around humans and can affect the development and behavior of people or groups. The environment influences the process of the entry of knowledge into individuals who are in the environment (Nasution, 2012).

\section{Smoker Family Members}

Based on the results of research in the field that researchers do in fact there are still many families in the settlement of PT. MIFA smokes a lot. Their reason is because if they don't smoke they cannot work due to a mind that cannot focus. Some said that when they were ready to eat they did not smoke, their mouths felt sour.

Smoking habits that are common in life. Winniford in Rizki (2014) cigarettes contain nicotine which can increase beats heart, systolic and diastolic blood pressure. Increased heart rate in smokers occurs in the first minute of smoking and after 10 minutes the increase reaches $30 \%$ while the systolic pressure rises to reach $10 \%$. Cigarettes are one of the industrial products and international commodities that contain around 1,500 chemicals. Important elements include: tar, nicotine, benzopyrin, methyl chloride, acetone, ammonia, and carbon monoxide (Bustan, M.N, 2012)

According to the Ministry of Health Republic of Indonesia Promkes Center (2013), it has been proven in research that in one cigarette contained 4000 dangerous chemical poisons including 43 compounds.

\section{CONCLUSION}

1. The number of unhealthy families is 178 households $(68.2 \%)$, respondents number of healthy families is 83 households $(31.8 \%)$.

2. Total index of healthy families as much as $31.8 \%$ of all unhealthy families. 


\section{REFERENCE}

Adib, M. 2011. Cara Mudah Memahami dan Menghindari Hipertensi, Jantung, dan Stroke. Dianloka Pustaka Populer. Yokyakarta.

Amin Z, Bahar A (2014). Tuberkulosis paru. Dalam : Aru W,Sudoyo B S,Idrus A,Marcellus S,Siti S, ed.Buku Ajar Ilmu Penyakit Dalam.Edisi ke-6 Jilid I. Jakarta:Pusat Penerbitan Departemen Ilmu Penyakit Dalam Fakultas Kedokteran Universitas Indonesia, pp : 86371.

Arikunto. 2012. Prosedur Penelitian - Suatu Pendekatan Praktik. Jakarta. Rineka Cipta.

Atika. (2010). Imunisasi dan Vaksinasi. Bantul, Yogyakarta Nuha Medika.

Azwar, Azrul. 20012 Menjaga Mutu Pelayanan Kesehatan. Pustaka Sinar Harga, Jakarta

Budiman. 2010. Metodologi Penelitian Kesehatan. Jakarta: Penerbit Buku Kedokteran EGC.

Bustan, M.N. 2012. Epidemiologi Penyakit Tidak Menular. Rineka Cipta. Jakarta.

Chayatin, N., \& Santoso, B. A. (2010). Ilmu keperawatan komunitas; Konsep dan aplikasi. Jakarta: Salemba Medika.

Cici dan Mila. 2017. Indikator Keluarga Sehat Di Kelurahan Lebak Bandung Kota Jambi. urnal Akademika Baiturrahim Cici Sahara, Mila Triana Sari, Vol.6 No.1 Maret 2017. STIKBA Jambi.

Dinkes Aceh Barat. 2016. Profil kesehatan Kabupaten Aceh Barat Tahun 2015. Aceh Barat.

Dinkes Aceh. 2016. Profil kesehatan Kabupaten Aceh Tahun 2015. Aceh.

Fauzi, Muzaham, 2010. Sosiologi Kesehatan. Universitas Indonesia (UI-Press), Jakarta.

Fauziah, A.N. (2016). Keluarga Sehat Berdasarkan Pendekatan Keluarga Di RW 03 Kelurahan Mojosongo Surakarta Tahun 2016. Surakarta :Akademi Kebidanan Mamba'ul'ulum Surakarta

Ferizal, Y Dan Hasanbasri, M. 2007. Proses Pelaksanaan Manajemen Pelayanan Posyandu Terhadap Intensitas Posyandu: KMPK Universitas Gadjah Mada.

Fitrijani. 2011. Aspek Kelembagaan Pada Pengelolaan Tempat Pemrosesan Akhir Sampah Regional (Institutional Aspects in the Management of Regional Final Waste Processing Site). Jurnal Permukiman, Vol. 6 No. 2 Agustus 2011 : 65-74. ISSN : 1907 - 4352., Pusat Litbang Permukiman

Friedman. 2010. Keperawatan Keluarga. Edisi 3. Jakarta: EGC.

Gery F. 2012. Obstetri Williams. (Suharyati Samba). Jakarta: EGC 
Hanum, 2010, Tumbuh Kembang, Status Gizi dan Imunisasi Dasar Pada Balita, Yogyakarta: Nuha Medika

Hartanto, Hanafi. 2012, Keluarga Berencana dan Kontrasepsi, Pustaka Sinar Harapan, Jakarta.

Hawigyo, 2016. Cara Mendapatkan Air Bersih, Balai Pustaka. Jakarta

Kemenkes RI. 2013. Riset Kesehatan Dasar. Jakarta.

Kemenkes RI. 2015. Indikator Indonesia Sehat 2016 dan Pedoman Penetapan Indikator Provinsi Sehat dan Kabupaten/Kota Sehat. Jakarta.

Kemenkes RI. 2015. Profil Kesehatan Indonesia. Jakarta.

Kemenkes. 2012. Panduan Promosi Perilaku Tidak Merokok. Pusat Promosi Kesehatan Depkes RI. Jakarta

Kepmenkes RI. 2018. Tentang Petunjuk Teknis Standar Pelayanan Minimal Bidang Kesehatan Di Kabupaten/Kota. Keputusan Menteri Kesehatan RI Nomor 828/Menkes/SK/IX/2018.Jakarta.

King, L. A. 2013. Psikologi Umum: Sebuah Pandangan Apresiatif. Salemba Medika. Jakarta.

Moeloek, Nila Farid,. 2014. Menkes Dorong Persalinan Harus Ditolong Tenaga Kesehatan dan di Fasilitas Kesehatan. Kampanye Peduli Kesehatan Ibu The Amazing Race yang bertema "Ibu Hebat Berlomba untuk Keluarga Sehat" Menkes RI.

Mu'rifah. (2012). “ Materi Pokok Pendidikan Kesehatan.” Jakarta: Universitas Terbuka.

Mubarak, W.I., Chayatin, N., dan Santoso, B.A., 2010. Ilmu Keperawatan Komunitas Konsep dan Aplikasi. Jakarta: Selemba Medika.

Notoatmodjo, S. 2010. Metodologi penelitian kesehatan. Rineka Cipta. Jakarta

Notoatmodjo, S. 2012. Promosi kesehatan dan Perilaku Kesehatan. Edisi Revisi. Jakarta: Rineka Cipta.

Novia dan Septariani. 2016. Survei Indikator Kesehatan Ibu Dan Balita Di Empat Kelompok Terpencil Banjar Dinas Muntigunung Tianyar Barat, Kabupaten Karangasem Bali. Jurnal Virgin, Jilid II, No. I, Januari 2016 ISSN : 2442-2509 Ilmu Kesehatan Masyarakat Fak. Kedokteran Universitas Udayana

PT. MIFA. 2018. Data pemukiman PT. MIFA. 
Ringga. 2017. Faktor dominan yang mempengaruhi phbs di permukiman kota padang. Jurnal Kesehatan Masyarakat Andalas |April 2017 - September 2017 | Vol. 11, No. 2, Hal. 6774. e-ISSN 2442-6725. Fakultas Kesehatan Masyarakat Universitas Andalas

Rini, Kustiani,. 2012). Program KB di Serahkan ke Daerah. http://interaktif.com/kb/nasional/2007/02/13/brk,20070213 93144.id.html.

Rizki Amaliah (2014). Faktor Yang Berhubungan Dengan Kapasitas Vital Paru Pada Pedagang Kaki Lima Terminal Induk Kabupaten Pemalang. Jurnal Universitas Negeri Semarang. (http://lib.unnes.ac.id) Diakses Tanggal 26 Juli 2015

Roesli, Utami. 2012. Buku Pintar ASI Eksklusif. Yogyakarta. Diva Press.

Salim, S. Abdool Karim, M.B. 2010. Timing of Initiation of Antiretroviral Drugs during Tuberculosis Therapy. N Engl J Med, 362: 697-706

Setiadi. 2013. Konsep dan Praktik Penulisan Riset Keperawatan. Graha Ilmu. Yogyakarta.

Soediutama, 2010. Ilmu Gizi Untuk Mahasiswa dan Profesi Jilid II. Jakarta: Dian Rakyat.

Soetjningsih. 2012. Tumbuh kembang Anak, Buku kedokteran, ECG. Jakarta.

Sugiarti E., Zulaekah S., dan Puspowati D.S., 2011. Faktor-Faktor Yang Berhubungan Dengan Pemberian ASI Eksklusif Di Kecamatan Karang Malang Kabupaten Sragen. Jurnal Kesehatan, ISSN 1979-7621, Vol. 4, No. 2: 195-206.

Sugiyono. 2010. Metode Penelitian Kuantitatif, Kualitatif dan R\&D. Bandung: Afabeta

Suhardjo. 2010. Perencanaan Pangan dan Gizi. Bumi Aksara dan Pusat Antar UniversitasPangan dan Gizi, Institut Pertanian Bogor.

Sulistyawati, A, 2013, PelayananKeluarga Berencana, Jakarta: Salemba. Medika

Susanto,. 2010. Cekal(Cegah dan Tangkal) Penyakit Modem. Yogyakarta: CV. Andi.

Suyono, Slamet. 2011. Buku Ajar Ilmu Penyakit Dalam, Jilid 2, Edisi Balai Penerbit FKUI, Jakarta.

Syafiq A, Fikawati S,. 2012. Status gizi ibu dan Persepsi Ketidakcukupan ASI. Kesmas: Jurnal Kesehatan Masyarakat Nasional. 2012; 6 (6): 249-54.

Syamsudin. 2011. Buku Ajar Farmakoterapi Kardiovaskular Dan Renal. Jakarta: Penerbit Salemba Medika pp 31

Syarif, la ode. 2011. Asuhan Keperawatan Gerontik Berstandartkan Nanda, NIC, dan NOC Dilengkapi Teori dan Contoh Kasus Askep. Nuha Medika: Yogyakarta. 
Tiarlin. 2018. Analisis Masalah Kesehatan Penduduk Berdasarkan 12 Indikator Keluarga Sehat Rumah Susun Tambora. Indonesia Jurnal Kebidanan Vol. 2 No.1 (2018) 14-23. Akademi Kebidanan Budi Kemuliaan.

Totok Sutrisno, dkk., 2010. Teknologi Penyediaan Air Bersih, Rineka Cipta. Jakarta.

Wade, C., dan Tavris, C. 2012. Psikologi. Edisike-9. Erlangga. Jakarta.

Walgito, B, 2014. Pengantar Psikologi Umum, Edisi V. Yogyakarta : C.V ANDI OFFSET

Wijono, M. S. 2010. Manajemen Mutu Pelayanan Kesehatan. Airlangga University Press

Wirdhaliani. 2017. Gambaran Indikator Keluarga Sehat di Gampong Lampulo Kecamatan Kuta Alam Banda Aceh. Jurnal Kesehatan Mahasiswa Keperawatan, Vol 2, No 3 (2017) ISSN . Universitas Syiahkuala. Aceh

Wirdhana, I., et al. (2013). Komunikasi Efektif Orangtua dengan Remaja. Jakarta: BKKBN.

Wong, DL (2014). Buku Ajar Keperawatan Pediatrik. Alih bahasa Agus Sutarna dkk, Jakarta :EGC

Yosep, I. 2010. Keperawatan Jiwa. Ed. Revisi. Cet. Ke-3. PT. Refika Aditama. Bandung.

Yundini. 2012. Faktor Risiko Hipertensi. Warta Pengendalian Penyakit Tidak Menular. Jakarta.

Yusmi, 2011, Imunisasi Dan Keuntungan Serta Efeknya Bagi Kesehatan, Thesis. Di Publikasikan. Jakarta. Fakultas Keperawatan Universitas Indonesia. 
